https://doi.org/10.22363/2312-8674-2020-19-1-78-94

Научная статья / Research article

\title{
Comrades in Arts: The Soviet Dekada of National Art and the Friendship of Peoples
}

\author{
Isabelle R. Kaplan \\ National Research University Higher School of Economics; \\ 21/4, Staraya Basmannaya St., Moscow, 105066 Russia; kaplanindc@yahoo.com
}

\section{Товарищи по искусству: фестиваль народного искусства и дружбы народов в СССР в середине 1930-х гг.}

\author{
И.Р. Каплан \\ Национальный исследовательский университет «Высшая школа экономики»; \\ 105066, Россия, г. Москва, ул. Старая Басманная, 21/4; kaplanindc@yahoo.com
}

\begin{abstract}
This article examines the dekady of national art, a series of Soviet festivals first staged in the mid-1930s to highlight the cultures and artistic accomplishments of the various non-Russian republics of the USSR. The institution of the dekada, I contend, made considerable contributions to Soviet nationbuilding efforts and the construction of multiethnic culture. The article unfolds in three sections. The first relies on archival documents to trace the origins and evolution of the dekada of national art in the context of its bureaucratic home, the All-Union Committee on Arts Affairs. The second draws largely on periodical sources to consider the ways in which the larger currents of Stalin-era culture are reflected in the dekady of national art and, in particular in the national operas that served as the centerpieces of the dekady. The final section turns to the Friendship of Peoples campaign, identifying one aspect of it - that Soviet citizens appreciate not only their own national art but the art of other Soviet nations - as central to the dekady. Analyzing the public rhetoric surrounding the dekady, I identify several themes that emerge and their implications for forging a common pan-Soviet culture. I conclude that it is not only national cultural production, but the consumption of national cultural products by a multiethnic audience that is central to nation-building on multiple levels as well as a means to unite the ethnically diverse Soviet people, and that the dekada festivals aimed to bring the Soviet nations closer together by providing them an opportunity to consume one another's cultural products.

Keywords: Dekada of National Art, Friendship of Peoples, Soviet republics, cultural production, cultural consumption, 1930s, national cultures

Acknowledgments: Writing and research for this article were supported by American Councils, Fulbright IIE, the US Embassy in Baku, the Azerbaijan Diplomatic Academy, Georgetown University, the University of Maryland-College Park, and the National Research University "Higher School of Economics." Portions were presented at ARISC, ASEEES, ICCEES and ASN conferences, and I am grateful to all panelists, discussants, and attendees for their feedback. Likewise, I extend my thanks to the two peer reviewers for their comments and suggestions.

For citation: Kaplan, Isabelle R., "Comrades in Arts: The Soviet Dekada of National Art and the Friendship of Peoples." RUDN Journal of Russian History 19, no. 1 (February 2020): 78-94. https://doi. org/10.22363/2312-8674-2020-19-1-78-94
\end{abstract}

(C) Kaplan I., 2019

This work is licensed under a Creative Commons Attribution 4.0 International License https://creativecommons.org/licenses/by/4.0/ 
Аннотация: В статье рассматривается советский опыт проведения декады или десятидневного фестиваля национального искусства, зародившегося в 1930-е гг. под названием «Дружба народов». Его целью было знакомство советской многонациональной аудитории с культурными достижениями отдельных народов СССР. В то время, как некоторые наблюдатели считают, что декада национального искусства - это просто демонстрация пропагандистского китча, автор статьи утверждает, что фестивали являлись важными площадками национального строительства в СССР. В рамках отдельной республики декада открывала возможность для формирования национальной идентичности, хотя и «официально санкционированной» версии, посредством художественного производства и гордой национальной самопрезентации. В то же время декада внесла свой вклад в создание всесоюзного, многоэтнического художественного канона, который призван был обеспечить важную особенность пансоветской идентичности. В статье отмечается, что декады национального искусства, с одной стороны, представляют собой очередную итерацию высокоэффективной советской пропаганды, воплощающей известные направления культуры сталинской эпохи. С другой стороны, эти фестивали стали важным событием в жизни советских наций и в советском национальном строительстве. Национальные культуры предоставили материал для построения международной культуры, так же как национальные продукты были строительными блоками интегрированной международной экономики. В качестве возможности для ритуального потребления всеми советскими народами избранных, одобренных Москвой, национальных продуктов, вносимых каждой братской республикой, фестивали Декады были направлены на содействие процессу культурной интеграции и построение единой советской идентичности. Рамки дружбы народов обеспечили многокультурную аудиторию, необходимую для того, чтобы сделать национальное искусство универсальным. Представление каждой нацией своего художественного продукта и восхищенного потребления его всесоюзной аудиторией было культурной операцией, посредством которой отдельная нация способствовала созданию общей советской культуры. В обмен была утверждена отдельная нация - «производитель». Таким образом, фестивали, подобные Декаде, предоставляли собой своеобразный механизм для развития всесоюзного, многонационального художественного канона, который, мог стать краеугольным камнем в здании единого советской идентичности.

Ключевые слова: декада народного искусства, дружба народов, советские республики, 1930-е годы, национальные культуры

Благодарности: Автор выражает благодарность за поддержку, оказанную Американским советом, Фулбрайтом IIE, посольством США в Баку, Дипломатической Академией Республики Азербайджан, Джорджтаунским университетом, Университетом штата Мэриленд-Колледж-Парк и Национальным исследовательским университетом «Высшая школа экономики». Я благодарна всем участникам дискуссий на конференциях, организованных ARISC, ASEEES, ICCEES и ASN, а также двум анонимным рецензентам за их комментарии и предложения.

Для цитирования: Каплан И.Р. Товарищи по искусству: фестиваль народного искусства и дружбы народов в СССР в середине 1930-х гг. // Вестник Российского университета дружбы народов. Серия: История России. 2020. Т. 19. № 1. С. 78-94. https://doi.org/10.22363/2312-8674-2020-19-1-78-94

\section{Introduction}

The title of the current issue of the present journal reminds us of Druzhba narodov (the Friendship of Peoples) as a feature of Soviet life. Some see it as an instrumentalist campaign devised in the mid-1930s to forge unity among an ethnically diverse population by trumpeting, if hypocritically, the equality of the "bratskii" [brotherly] peoples of the Soviet Union against a backdrop of an officially sanctioned rising Russocentrism. ${ }^{1}$ One scholar has identified "the rehabilitation of traditional Russian culture and Russian nationalism as

1 Terry Martin, The Affirmative Action Empire: Nations and Nationalism in the Soviet Union, 1923-1939 (Ithaca, NY: Cornell University Press, 2001), 270, 441; A formalized, official Friendship of Peoples rhetoric appeared in 1935 and quickly became ubiquitous as an obligatory part of Soviet fustian for all government channels. 
a force for Soviet unity" as a "major feature of the Friendship of Peoples." For others, the phrase encapsulated the notion of internationalism, which despite some fluctuations in meaning, remained a fundamental tenet of Soviet ideology that preceded the Stalin era and remained relevant long after. ${ }^{3}$ In this broader understanding, the Friendship of Peoples ethos was, arguably, part of a set of Soviet policies that fostered interethnic cooperation so meaningful it was a factor in mitigating ethnic violence during World War II. ${ }^{4}$

This article takes as its focus the dekada, or ten-day festival, of national art, a Soviet institution born in the 1930s under the Friendship of Peoples rubric that aimed to bring the individual cultures of non-Russian Soviet nations to the attention of the broader, multiethnic audience of the USSR. While some observers have dismissed the dekada (pl. dekady) of national art as a mere display of propagandistic kitsch, I have argued that the festivals could be important sites of active nation-building on two discrete but interconnected levels. For the republic taking the stage, the dekada provided important opportunities for the forging of national identity, albeit the "officially sanctioned" version, through artistic production and proud national self-presentation. ${ }^{5}$ At the same time, I contend, the dekada contributed to the project of constructing an all-Union, multi-ethnic artistic canon that could furnish an important feature of pan-Soviet identity. The present analysis unfolds in three sections. The first relies on archival documents to portray the origins and evolution of the dekada of national art in its institutional setting. The second draws largely on periodical sources to show that the institution was not a mere outgrowth of Soviet nationalities policy but a product of Soviet 1930s culture more generally. The final section illustrates how the festivals employed the most salient cultural forces of the era to serve the needs of Soviet nationalities policy, mobilizing the period's emphasis on production and consumption as a means to unite the ethnically diverse Soviet people. ${ }^{6}$

\section{The Dekada of National Art and Institutional Context}

Between 1936 and 1941, ten dekady of national art were presented in Moscow, each celebrating the artistic accomplishments of a different non-Russian ethnic group of the Soviet Union (See Table 1).?

2 Terry Martin, The Affirmative Action Empire: Nations and Nationalism in the Soviet Union, 1923-1939 (Ithaca, NY: Cornell University Press, 2001), 441.

3 While early on Soviet internationalism referred to all humankind, Yuri Slezkine asserts that in the 1930s "internationalism" and "Friendship of Peoples" alike referred to "close ties among Soviet nationalities." Yuri Slezkine, "The USSR as a Communal Apartment, or How a Socialist State Promoted Ethnic Particularism," Slavic Review 53, no. 2 (Summer 1994): 443; Later on, the term "Friendship of Peoples" came to encompass non-Soviet groups as well.

4 Diana Dumitru, and Carter Johnson, "Constructing Interethnic Conflict and Cooperation: Why Some People Harmed Jews and Others Helped Them during the Holocaust in Romania," World Politics, no. 61/1 (January 2011): 1-42.

5 Jeffrey Brooks refers to the "officially sanctioned non-Russian cultures" on display at the dekady. See Jeffrey Brooks, Thank You, Comrade Stalin! Soviet Public Culture from Revolution to Cold War (Princeton, NJ: Princeton University Press, 2000), 96. The dekady have been described as Moscow's "favored symbolic demonstration" of the Friendship of Peoples. (Martin, The Affirmative Action Empire, 439) One conference panel discussant referred to the national art dekady as instances of "Disneyfication."

6 On the role of the festivals in forging local national identities, see Isabelle R. Kaplan, The Art of Nation-building: National Culture and Soviet Politics in Azerbaijan and Other Minority Republics (PhD diss., Georgetown University, 2017).

7 Dekady of national art were presented by the titular ethnic groups of Union-level republics and sometimes by groups with an autonomous republic within the RSFSR (for example, the Buriat-Mongol 
Pre-World War II Dekady of National Art in Moscow

\begin{tabular}{|c|c|}
\hline Republic & Dates of dekada \\
\hline Ukrainian SSR & 10-21 March 1936 \\
\hline Kazakh SSR & 17-25 May 1936 \\
\hline Georgian SSR & 5-15 January 1937 \\
\hline Uzbek SSR & 21-30 May 1937 \\
\hline Azerbaijani SSR & 5-15 April 1938 \\
\hline Kirgiz SSR & 26 May - 4 June 1939 \\
\hline Armenian SSR & 20-29 October 1939 \\
\hline Belorussian SSR & 5-15 June 1940 \\
\hline Buriat-Mongol ASSR & 20-27 October 1940 \\
\hline Tajik SSR & 12-21 April 1941 \\
\hline
\end{tabular}

Source: RGALI, f. 962, op. 21, d. 2, passim.

Held under the auspices of the newly created All-Union Committee of Arts Affairs of the SNK SSSR [Всесоюзный комитет по делам искусств при СНК СССР], which aimed to unify control over all aspects of the arts, the dekady were organized by the local directorates [управления] of arts affairs established in each republic. The publicly stated purpose of the dekady of national art was to demonstrate the success of Soviet nationalities policy, specifically, the nation-building activities fostered by this policy in the area of culture. For each ten-day festival, the "host" republic sent a delegation of hundreds of artists and performers to Moscow to present an extravagant, carefully planned cultural program that included the full complement of what, in Moscow's view, exemplified the cultural achievements of a mature nation. These, for the series of pre-war dekady examined here, were in large part localized around the activities of the opera and ballet theater in each republican capital. Collectives housed at these respective theaters typically included an opera or musical drama troupe, a ballet troupe, and a symphony orchestra, which became the nucleus of the national art dekada. Other ensembles that became staples of national art dekady included an orchestra of "national instruments," a national dance group, amateur singing and dance collectives, and a children's choir.

The first national art dekada in Moscow, that of Ukrainian art held in March 1936, was initially organized by the All-Union Committee of Arts Affairs' Directorate of Theaters as part of a series of tour dates by the Kiev State Opera and Ballet Theater in Moscow and Leningrad. Early planning documents refer to the events as the "Dekada of Ukrainian Musical Art," which is explained as a "showing of Ukrainian musical creative work and excellence in performance” [«показ Украинского музыкального творчества

ASSR). Following World War II, the tradition continued, with dozens more dekady of national art held in Moscow. By the 1960s the model expanded to bypass Moscow and establish periphery-to-periphery contacts through events such as the 1966 Dekada of Belorussian Art in Uzbekistan. 
и исполнительского мастерства»]. ${ }^{8}$ In a February 1936 letter to All-Union Committee of Arts Affairs Chair P.M. Kerzhentsev, acting chair of the new Directorate of Arts Affairs of the Ukrainian SSR A.A. Khvylia outlined the dekada activities: Following an opening concert given by Bolshoi Theater performers at the Colonnade Hall of the House of Unions [Колонный зал Дом Союзова] to welcome the Ukrainian visitors, the Kiev State Academic Opera and Ballet Theater took the stage of the Bolshoi Theater across the street for ten days, presenting performances of three operas: two by Ukrainian composers as well as a Russian classic, sung in Ukrainian. The "tour" would conclude with "a concert of Ukrainian folk songs and dances" [«концерт украинской народной песни и танца»], which would feature a variety soloists along with groups such as a capella singers, a women's choral ensemble, bandura players, and the Ukrainian Red Army amateur [самодеятельный] ensemble. The groups would bring all scenery and costumes with them from Kiev, as well as a staff of stagehands, along with Ukrainian and Russian editions of booklets with summaries and other information about each opera. ${ }^{9}$ Thus a range of Ukrainian musical culture was on display at the dekada.

While the above outline of the Ukrainian festival established a format repeated in subsequent dekady of national art, there are visible variations that address the individual circumstances of one or another republic. In addition, some features of the 1936 dekady (Ukrainian, Kazakh) appear to compensate for the limited organizational capacity of a new arts bureaucracy - the All-Union Committee of Arts Affairs - that was still taking shape in the first months of 1936. For example, the Ukrainian arts chief, Khvylia, informed Kerzhentsev of where the dekada participants would be staying while in Moscow, and it is the administration of the Moscow State Philharmonic, under N.N. Kuliabko, that draws up a budget for the Ukrainian dekada and presents it to Kerzhentsev's All-Union Committee. ${ }^{10}$ For later dekady of national art of the pre-war period, an organizational committee [оргкомитет] of All-Union Committee on Arts Affairs officials in Moscow was appointed to oversee such logistical aspects of the festivals. In contrast, the first three months of 1936 saw the new arts committee appointing its core staff in Moscow, confirming leadership of arts directorates in the republics, and inventorying the vast web of arts institutions now under its control. Khvylia, the arts official in Kiev, was confirmed as head of the Ukrainian Directorate of Arts Affairs on 16 March 1936, as his dekada was taking place in Moscow. ${ }^{11}$ While the participants of the Ukrainian dekada in 1936 were scheduled to give a series of concerts at Moscow State Conservatory, there is no evidence of analogous appearances in connection with subsequent festivals. ${ }^{12}$ Since the Moscow State Philharmonic's involvement in dekada organization is limited to the Ukrainian experience, one wonders if the All-Union Committee's first dekada plans in February 1936 were relying on pre-existing tour engagements, and organizational infrastructure, perhaps out of necessity.

8 Rossiiskii gosudarstvennyi arkhiv literatury i iskusstva (henceforth RGALI), f. 962, op. 21, d. 67, 1. 22.

9 Ibid., 11. 19-21.

10 Ibid., 11. 21, 26, 31-30 ob.

11 RGALI, f. 962, op. 3, d. 23, 1. 85; Before his appointment as head of the new arts directorate, Khvylia had held a leadership position in the Narkompros of the Ukrainian SSR. On Khvylia, see Mayhill C. Fowler, Beau Monde on Empire's Edge: State and Stage in Soviet Ukraine (University of Toronto Press, 2017).

12 RGALI, f. 962, op. 21, d. 67, 1. 23. 
Planning documents for the Dekada of Kazakh Art, held in Moscow just two months later, in May 1936, likewise, reveal terminological uncertainty and organizational contingencies. Apart from the occasional use of 'dekadnik' (rather than 'dekada,' which quickly became the term used for the festivals of national art), Kazakh planning is notable for the unusually large role of the Writers' Union, both in Moscow and its local branch in the Kazakh capital. One reason for this could be the nascent state of the republican (and, in fact, all local) arts directorates; in contrast, the Union of Soviet Writers, which had existed since 1934, had had time to develop an infrastructure in the national republics, including channels of communication with Moscow, as well as its own financial resources and allotments. Thus, another possible reason is budgetary. The position of the All-Union Committee on Arts Affairs at this point was that, while there was certainly interest in a series of festivals of national culture of the peoples of the USSR, the arts committee itself did not have sufficient funds to support it and was not in a position to ask the Sovnarkom to dip into its reserve fund. So, deputy head of the arts committee's Main Directorate of Theaters, who had been looking into the feasibility of a Kazakh "dekadnik" in response to a query from the chair of the board of the Writers' Union and Commissar of Enlightenment of the Kazakh ASSR, concluded, if "the Kazakhstani organizations want to, they will find the money."13 The Kazakh festival, sometimes referred to as the "Dekada of Kazakh Art and Literature," included alongside performances by the Kazakh State Musical Theater and Kazakh State Philharmonic, a program of literary evenings, some with musical performances, the costs of which were covered by the Board of the Union of Soviet Writers of the USSR [Правление Союза Советских Писателей СССР]. ${ }^{14}$

As the dekady of national art continued to evolve, they became more expansive, with larger delegations traveling to Moscow and new art forms included in the programing. For example, during the Dekada of Georgian Art in January 1937, the latest films produced by the republic's Goskinoprom studio were screened in Moscow movie theaters. The delegation that went to Moscow for the Dekada of Belorussian Art in June 1940 included a group of architects, whose travel expenses were covered by the board of the Union of Soviet Architects [Правление Союза Советских Архитекторов]. ${ }^{15}$ As the AllUnion Committee on Arts Affairs gained strength and resources, it solidified its control over the dekady and its ability to shape them. The arts committee was able to arrange approval of ever larger funding allocations for dekada preparation in republican yearly budgets, and when time was too short to include such provisions the committee asked the SNK to provide extra resources. For example, archival documents show that planning for the Dekada of Belorussian Art had begun in April 1939, with a projected delegation of 435 , but when newly annexed territory pushed the republic's borders westward, authorities rushed to expand the festival to match the enlarged BSSR. The unforeseen expenses of a delegation that ballooned to well over 1000 were borne by the SNK SSSR. ${ }^{16}$

The Great Terror, which targeted the creative elites of the national republics in particular, did not leave dekada planning unscathed; it is telling that between May 1937 and May 1939 the only dekada held in Moscow was that of the Azerbaijani SSR. Fol-

13 RGALI, f. 962, op. 21, d. 38, 1. 22; The Enlightenment Commissar, Temirbek Zhurgenov, was also appointed the head of the Directorate of Arts Affairs, holding both posts simultaneously.

14 Ibid., 11. 19-19 ob.

15 Ibid., d. 26, 11. 3, 48.

16 Ibid., 11. 68-71, 14, 12; Ibid., f. 962, op. 21, d. 27, 11. 1-67. 
lowing these upheavals, however, dekada preparation became routinized under Mikhail Khrapchenko, the new chair of the All-Union Committee on Arts Affairs. The arts committee in Moscow determined if and when a republic was ready to undertake a dekada, issuing its timeline and budget recommendations to the SNK. It sent staff to assist republics in their preparation work and sent a brigade to preview each dekada program in a republic's capital before festival dates could be finalized.

Still, the emergence of procedural stability notwithstanding, central features of the dekada of national art were apparent from the start, with the Kiev State Academic Opera and Ballet Theater performing national works on the stage of Moscow's Bolshoi Theater before an audience of arts, government, and Party elites. Organizationally and conceptually, the dekada of national art was rooted in the theater. Unlike the Union of Soviet Writers, which had a section devoted to nationalities, the All-Union Committee on Arts Affairs did not. The framers and runners of the dekady of national art in Moscow came from the Main Directorate of Theaters of the All-Union Committee.

\section{The Dekada of National Art and 1930s Culture}

Given its grounding in the theater, it is perhaps not surprising that from start to finish, each ten-day festival of national art was about staging and choreography, both literally and metaphorically. A dekada's gala opening was typically the Moscow premiere of a national opera presented at the Bolshoi Theater with top state and Party brass, including Stalin, in attendance. A lavish final concert was followed by a Kremlin reception for the visiting delegation and luminaries of the Moscow arts world. In between, Moscow audiences were treated to a cultural program that included everything from folk dance to ballet, from folk instruments to full symphony orchestra. Each dekada was conceived as a showcase for evidence of mature nationhood and cultural progress, and for the arbiters of dekada success at the All-Union Committee on Arts Affairs, an original Western-style grand opera in the republican language was an essential artifact. So important was the presentation of such a work that one critic sourly summarized the Dekada of Uzbek Art held in 1937 as falling short of expectation "because it lacked a national operatic spectacle on a large scale." ${ }^{17} \mathrm{Ge}-$ nerally speaking, republics strove to present multiple operas in their dekada repertoire, ideally including one based on a folk legend, national epic, or event from the national past and one based on revolutionary history or Soviet life.

A variety of factors underlay this fixation on grand opera as a litmus test for national development, and therefore its requisite presence at the center of each dekada program. ${ }^{18}$ Such influential cultural figures as Anatolii Lunacharskii saw opera's potential

17 Rena Moisenko, Realist Music: 25 Soviet Composers (London: Meridian Books, 1949), 238. There were some who referred to works presented at the Uzbek dekada as "operas," while others disparagingly called them "musical dramas."

18 A number of scholars have pointed out have pointed out the particular importance of opera in the Soviet cultural pantheon as well as its particular role in the development of Soviet national art. See, for example, Marina Frolova-Walker, " "National in Form, Socialist in Content': Musical Nation-Building in the Soviet Republics," Journal of the American Musicological Society 51, no. 2 (Summer 1998): 335, and Martin, The Affirmative Action Empire, 440. To facilitate the generation of national operas, central authorities dispatched recent graduates of Moscow and Leningrad conservatories to republics perceived as in need of assistance, particularly in Central Asia. 
to "transform consciousness" and therefore its value to the revolution. ${ }^{19}$ Yet the operatic genre that the (predominantly Russian) dekada architects at the All-Union Committee on Arts Affairs wanted to see uniquely epitomizes their cultural moment. They wanted grand national operas like those Europe produced in its age of nationalism, works that would do for each national republic what Glinka had done for Russia, that wove together different branches of the arts to achieve a unified, monumental whole. ${ }^{20}$ Such artistic output aptly befit the public culture of the era. This section examines how several prominent currents in Soviet 1930s culture mapped onto the dekady of national art.

Pageant - Celebration - Competition. Alongside events such as parades in Red Square and the All-Union Agricultural Exhibition that opened in Moscow in 1939, the dekada of national art belongs to the genre of large-scale public celebrations that by the late 1930s had overrun the Soviet calendar. These extravaganzas were evidence of Stalin's 1935 declaration that life had become better, which ushered in a new era that demanded exuberant expressions of joy from individual and collective alike. ${ }^{21}$ In arts and athletics, the olimpiada and spartakiada formats showcased "socialist competition" in the service of celebrating Soviet achievement. In contrast to parades in which each republic marched ostensibly as an equal partner in the Soviet family of nations (with the exception of Russia, which was "first among equals"), contests made space for winners and thus explicitly invited comparison among participants. ${ }^{22}$ The dekada of national art, which focused on one republic at a time, did not officially include competition or even comparison between nations; instead, it offered each its moment in the spotlight on the all-Union stage.

Yet the "sibling rivalry" among national republics is evident in conversations among dekada planners. A member of Azerbaijan's dekada-planning committee referred to one opera on the republic's program as the Azerbaijanis" "trump card" because it was "a response to all the problems that neither Georgia nor Ukraine solved" in their dekady. ${ }^{23}$ The planning committee in Baku agreed that Azerbaijan must bring to Moscow a choir at least as large as the ones the Georgians and Uzbeks had brought to their dekady. ${ }^{24}$ The statements of the authorities encouraged these comparisons by stressing that each republic should learn from previous dekady. At a June 1937 meeting with participants of the Dekada of Uzbek Art, which had just ended in Moscow, a deputy chair of the All-Union Committee discussed the high and low points of the festival, saying this stock-taking would be instructive not only for the Uzbeks but for all national republics, who, of course, want to present Moscow with the best they can. To facilitate this, a summary of the Uzbek dekada "results" would be pub-

19 Marina Frolova-Walker, "The Soviet Opera Project: Ivan Dzerzhinsky vs. Ivan Susanin," Cambridge Opera Journal 18, no. 2 (July 2006): 188.

20 Frolova-Walker, " "National in Form, Socialist in Content," " 339.

21 Evgenii Dobrenko, "Naideno v perevode: rozhdenie sovetskoi mnogonatsional'noi literatury iz smerti avtora," Neprikosnovennyi zapas, no. 4 (July-August 2011): 246.

22 Karen Petrone describes the 1939 Physical Culture Parade in Red Square, in which the Russian delegation marched behind a banner emblazoned with these words. See Petrone, Life Has Become More Joyous, Comrades: Celebrations in the Time of Stalin (Bloomington, IN: Indiana University Press, 2000 ), 35.

23 Republic of Azerbaijan State Literature and Art Archive named for Salman Mümtaz (henceforth ARDӘİA), f. 361, siy. 1, iş 17, səh. 259; Ukraine's dekada had been the first, held in March 1936.

24 ARDOİA, f. 361, siy. 1, iş 18, səh. 27; State Archive of the Republic of Azerbaijan (henceforth ARDA), f. 411, siy. 19 , iş 317 , səh. $32,57$. 
lished and distributed to the national republics as an aid in their own dekada preparations. ${ }^{25}$ The comments of political and artistic leaders reveal an anxious awareness of the dekada's meaning and what was at stake. Secretary of the Central Committee of the Communist Party of Kirgiziia K. Dzhanaliev was cognizant in 1939 that the creative community of his republic had been summoned to Moscow to submit its artistic products for approval: "we realize that the dekada is an exam of the artistic and ideological [orthodox political] maturity of the theatrical and musical culture of Kirgiziia."26

Unity and Integration. Some have argued that the mass celebrations of the 1930s reflected the state's "attempt to create a Soviet identity" and "a unified country out of ethnically diverse and geographically dispersed territories," commenting that such moves "remained in tension with efforts to promote the development of the individual nationalities that made up the Soviet Union." 27 Indeed, the sequence of the initial dekady of national art before World War II underscores the festival as a ritual of integration.

The choices of Ukraine and Kazakhstan as the first two republics to present a dekada in Moscow seems beyond coincidence. The invitation to the Ukrainians may have been part of the "dramatic revival of Ukrainization" in 1935-36 following the de-Ukrainization connected with the Skrypnyk affair in 1932-34. ${ }^{28}$ The welcoming to Moscow of one of Ukraine's premier cultural institutions in March 1936 served as evidence of the Stalinist state's esteem for Ukraine even as it bound the republic to the center. The Kazakh dekada in May 1936, celebrated the republic's accession from autonomous ethnic republic within RSFSR to Union-level status, a promotion said to reflect the "consolidation of the Kazakh people into a nation," which was an evolutionary step credited to Soviet nationalities policy. ${ }^{29}$ A newly "reunited" Belorussia rushed to present a dekada in June 1940 that included collectives from the western as well as the eastern part of the republic. By this time the Sovietized Baltic republics of Lithuania and Estonia had already begun planning their respective dekady of national art. ${ }^{30}$ In the words of one contemporary observer, the dekada of national art was a ritual "necessary for the creation of true Soviet citizens, for the knitting together of the vast State." 11

The Stakhanovite Treatment. The dekada of national art projected Stakhanovite culture into the artistic sphere, starting with the term 'dekada' itself, which is connected with early Soviet attempts to reconfigure the conventions of measuring time so as to "rationalize" production. Rather than seven-day weeks, the early Soviets sought to establish a ten-day pe-

25 RGALI, f. 962, op. 21, d. 62, 11. 42-46.

26 K. Dzhanaliev, Iskusstvo Sovetskoi Kirgizii (M.: Iskusstvo, 1939), 7. Vis-à-vis the Asian republics, the Soviet concept of cultural maturity implied Westernization of artistic forms.

27 Petrone, Life Has Become More Joyous, 10-11; Petrone is hardly alone in pointing out the tensions in Soviet nationalities policy. The theme of the policy's ambiguities and contradictions is an organizing principle of Terry Martin's The Affirmative Action Empire.

28 Martin, The Affirmative Action Empire, 368.

29 Semyon Dimanshtein, quoted in Martin, The Affirmative Action Empire, 447.

30 Pravda, September 29, 1940; Ibid., October 5, 1940, 1; RGALI, f. 962, op. 21, d. 43, passim; Ibid., f. 962, op. 21, d. 71, passim; These dekady, along with those of the Tatar and Bashkir ASSRs, were preempted by the war.

31 Moisenko, Realist Music, 34. 
riod, the dekada, as the standard temporal unit for measuring output. ${ }^{32}$ As Stalin's Five-Year Plans shifted the USSR into high gear, and the production cycle - setting, (over) fulfilling, and celebrating output goals of all kinds - began to structure the rhythm of public life, entire factories planned Stakhanovite shifts, Stakhanovite days, and Stakhanovite ten-day periods, referred to as dekady, during which a given enterprise or entire industry was challenged to maintain a Stakhanovite pace of production for the designated period. ${ }^{33}$ Outstanding performances earned individuals and worker brigades trips to Moscow, where they were greeted by high-ranking Party officials at celebratory receptions, showered with gifts, and indulged with shopping sprees of consumer goods in the capital. ${ }^{34}$ In this way, the dekada became the unit of time used to describe not only outstanding feats of production but of celebratory consumption. ${ }^{35}$ "Heroes" of dekada cultural production were rewarded much the same way as their coal-mining and cotton-harvesting comrades: at the conclusion of each dekada of national art, awards, which frequently carried a cash prize, were distributed, with honors and "valuable gifts" bestowed upon members of each delegation. The Azerbaijani State Opera and Ballet Theater, for example, left Moscow with the Order of Lenin. ${ }^{36}$ The day after each dekada-concluding Kremlin reception, Pravda published a list of dekada awardees and their photographs on the front page. Under arts committee chair Mikhail Khrapchenko, dekada delegations were permitted a shopping trip to a Moscow closed distribution store. ${ }^{37}$

Press coverage of an upcoming dekada of national art included regular dispatches from the republican capital detailing preparation up to a year in advance. In keeping with the spirit of the Stakhanovite era, the language of speed and numbers loomed large in such pieces. For example, a Pravda article that appeared in the run-up to the Dekada of Armenian Art, held in October 1939, cited 1,764 costumes sewn especially for the festival and the 40 railway cars required to transport everything to Moscow from Erevan. ${ }^{38}$ Another piece boasted that the staff of the Buriat-Mongol drama theater had increased from 60 to 250 in the short years since its founding. ${ }^{39}$ Even warnings not to let productivity fall once the dekada was over were common to the economic and artistic spheres. ${ }^{40}$

32 The term traces to the French Revolutionary calendar, which established a year of twelve 30-day months, with each month divided into three ten-day "weeks" (décades). See Matthew Shaw, Time and the French Revolution: A History of the French Republican Calendar, 1789-Year XIV (Woodbridge, Suffolk UK: The Boydell Press, 2011).

33 Lewis Siegelbaum, Stakhanovism and the politics of productivity in the USSR, 1935-1941 (Cambridge, UK: Cambridge University Press, 1988), 101; Stephen Kotkin, Magnetic Mountain: Stalinism as Civilization (Berkeley, CA: University of California Press, 1995), 207.

34 See, for example, Pravda coverage of the First All-Union Congress of Stakhanovites, which began on 17 November 1935 .

35 Siegelbaum identifies the link between the production of goods and their consumption as a feature of Stakhanovite culture. See Siegelbaum, Stakhanovism, chapter 6.

36 Pravda, April 18, 1938; This was not unusual. Following a dekada of national art, the participating republican state opera and ballet theater typically left Moscow with the Order of Lenin, though Serhy Yekelchyk notes that the awarding of the Order of Lenin to the Kiev Opera Theater at the conclusion of the Ukrainian dekada in January 1936 was "the first time a theater company had ever received the highest Soviet award." Yekelchyk, "Diktat and Dialogue in Stalinist Culture: Staging Patriotic Historical Opera in Soviet Ukraine, 1936-1954," Slavic Review 59, no. 3 (Autumn 2000): 601.

37 RGALI, f. 962, op. 21, d. 32, 1. 35; Ibid., f. 962, op. 21, d. 20, 1. 18.

38 “Dekada armianskogo iskusstva v Moskve," Pravda, September 3, 1939.

39 "Rozhdeniie teatra," Pravda, 5 June, 1940, 4; "Dekada buriat-mongol'skogo iskusstva v Moskve," Pravda, August 18, 1940, 4.

40 Siegelbaum, Stakhanovism, 110. M.V. Khrapchenko, "Rastsvet natsional'nogo iskusstva," Pravda, October 31, 1940, 2. 
The dekada of national art, then, takes cues from a familiar cultural script of the Soviet 1930s. Yet, at the same time, the unique dekada format of singling out one ethnic republic at a time on the all-Union stage brings into relief a different approach to realizing the Friendship of Peoples, one that is more complex than national delegations parading across Red Square or ethnically diverse comrades marching arm-in-arm towards the bright future.

\section{The Dekada of National Art and the Friendship of Peoples}

Under the capacious banner of Druzhba narodov, public demonstrations of Soviet diversity inevitably doubled as celebrations of Soviet unity. Yet some fields of endeavor are more amenable to such multitasking than others. In the sphere of national cultural production, which so many scholars of nationalism have described as a key element in the process of creating national identity, the target audience is typically imagined as members of the nation, in whom the sentiment of national belonging is awakened or appealed to. In other words, national art is meant to be consumed by the nation. The Friendship of Peoples, however, required that "all Soviet nationalities be deeply moved by the art of other Soviet nationalities" -- that is to say, national art of the kind that helps build nations was permissible in the Soviet context so long as it was shared beyond the national audience. ${ }^{41}$ Vehicles such as the dekada of national art aimed to facilitate this sharing. This section identifies three themes that emerge from the copious press coverage of the national art dekady as central to the regime's portrayal of cross-cultural exchange among Soviet peoples.

The National Interest. Dekada press coverage was studded with public proclamations of interest in and esteem for the cultures of all the nations of the Soviet Union. News articles stressed the packed Moscow houses that greeted dekada performances, and the capital's arts establishment penned testimonials expressing their joy and gratitude at the opportunity for exposure to the brilliant culture of this or that brother republic, of which they had previously known so little and now had so much appreciation. (While informational pieces in the central press sometimes represented non-Russian voices, the testimonial genre was typically written by ethnic Russians, who dominated the Moscow arts intelligentsia that largely comprised the theater audience for dekada performances). Following the Dekada of Tajik Art in 1941, People's Artist of the RSFSR B. Livanov wrote, "Until now we didn't know Tajik art. It has brought and will yet bring much benefit to us Muscovites..."42 In his article "Results of the Ukrainian Dekada," arts committee chief Platon Kerzhentsev attributed the festival's success to "the high quality of the Ukrainians" as well as to "the interest and love for Ukrainian culture that lives strongly among the workers of Moscow." 43 A piece about the Armenian dekada comments that the tsarist regime did as much as it could to isolate nations from one another, adding that in 1916 Armenian poetry was terra incognita for most Russians. ${ }^{44}$ "Tsarist Russia," wrote one music critic in an article preceding the 1937 Dekada of Georgian Art, "did not know any Georgian folk songs and did not want to

41 Slezkine, "The USSR as a Communal Apartment," 447.

42 Pravda, April 26, 1941, 4.

43 P. Kerzhentsev, "Itogi ukrainskoi dekady," Pravda, March 22, 1936, 4.

44 Sovetskoe iskusstvo, October 30, 1939. 
know." ${ }^{45}$ Such statements implied the resounding success of Soviet nationalities policy: not only had it allowed national cultures to flourish, but it had transformed Russians into an audience eager to appreciate the cultures of other republics.

This image of the center's reception of Soviet diversity departs from the one created at events such as the annual Physical Culture Parade in Red Square, where the gymnastics displays devised and performed by each national delegation defined their republic "by their economic or military contributions to the Soviet Union." Thus, for instance, in Uzbekistan's routine for Moscow's physical culture parade in 1939, "the Uzbek nation was reduced to a giant cotton field," 46 suggesting a Soviet centerperiphery relationship that differed little from the old model of the imperial nation exploiting its colonies for labor and raw materials. ${ }^{47}$ In contrast, the dekada format (focus on arts, one republic at a time) shifted attention to each republic's refined cultural output; these finished intellectual products, rather than raw materials, were its contribution to the Soviet whole. ${ }^{48}$ Moscow's consumption of these "artistic goods" represented progress on all sides: the ethnic periphery was now in a position to deliver valuable, high-quality art, and the Russian center, its previous cultural chauvinism withered by Soviet multicultural enlightenment, demonstrated its own development through its interest in national cultures, desire to learn from them, and ability to appreciate their quality.

A piece that ran in an Azerbaijani newspaper in the wake of the republic's arts dekada in 1938 serves to illustrate the significance ascribed to the center's consumption of national cultural products imported from the periphery. It quotes Alexei Stakhanov himself wishing Azerbaijan's workers the same level of success in the oil and cotton fields that the republic's artists had achieved in cultural production, suggesting that Azerbaijani culture, rather than Azerbaijani oil, had made the republic's greatest, most valuable contribution to socialist construction (and everyone knew the important role Azerbaijan's oil played in socialist construction). ${ }^{49}$ Moscow's appreciation of Azerbaijani art was a sign of esteem and prestige highly craved in Baku. Consumption during the dekady of national art enriched all participants, producer and consumer alike. Here the art of one Soviet nationality was edifying and moving audiences of other Soviet nationalities, strengthening the bond of friendship among Soviet peoples.

Accessibility. The dekada of national art was not only a paean to the sagacity of Soviet nationalities policy but also an opportunity to demonstrate the universality of human culture. Despite the often-noted importance accorded the written word in Soviet culture, the dekady of national art before World War II emphasized music and dance, with, as noted earlier, a particularly high premium placed on opera. ${ }^{50}$ There were likely pragmatic reasons

45 Sovetskoe iskusstvo, September 17, 1936.

46 Petrone, Life Has Become More Joyous, 36, 37. Petrone, noting the existence of a hierarchy of national groups, observes that Christian republics such as Georgia and Armenia had more freedom to make national cultural references than Muslim republics such as Azerbaijan and those of Central Asia. (38-9)

47 Ibid., 37.

48 In his discussion of the dekady of national art in the 1930s, Jeffrey Brooks writes, "the press presented the dekady as offerings to the state and Russian people, and, in that sense, as a consumer good." (Brooks, Thank You, Comrade Stalin, 96)

49 "Hər sahədə qələbə uğrunda mübarizəjə!" Qommunist, April 14, 1938.

50 Within a few years, republics began to hold separate literary dekady in Moscow devoted to the printed and spoken word - for example, in 1940, Azerbaijan presented the Dekada of Azerbaijani Literature 
for this. For one, the translation of literature into Russian, let alone the other languages of the Soviet Union, was time- and resource-consuming. ${ }^{51}$ Second, the expectation of delivering a republic's most cherished cultural achievements in Russian translation might undercut the image of freedom and flowering of non-Russian cultures that the dekada of national art was intended to celebrate. In the run-up to the first dekada of national art, that of Ukraine, in 1936, Ukrainian opera singer Oksana Petrusenko described in Pravda the thrill of rehearsing at the Bolshoi preparing to perform an opera in Ukrainian, as in her youth under the tsarist regime Ukrainians had not been permitted to print books in their own language. ${ }^{52}$ So forcing national acting talent to come to Moscow and perform their national art in Russian would not do. Furthermore, language-based genres such as non-musical theater could obstruct or compromise the delivery of messages about unity and mutual understanding. In other words, the language barrier might obstruct the goal of one national group being moved by the art of another national group. Music, as a universal language, was a hedge against this problem.

Indeed, insistence that language was not a barrier to the fullest reception of national art by the non-national audience was a staple of dekada press coverage. During the Dekada of Kazakh Art in 1936, All-Union Committee of Arts Affairs chairman Kerzhentsev marveled at how scenes from two Kazakh operas "evoke[d] reactions from audience members who don't even know Kazakh." ${ }^{53}$ Similarly, a Moscow critic remarked in his review of the closing concert of the Dekada of Armenian Art in 1939 that "even not knowing Armenian did not keep the audience from enjoying" the songs. ${ }^{54}$ Alexei Stakhanov noted the same phenomenon with regard to the Azerbaijani dekada, enthusing that the performers were so excellent that the audience's lack of knowledge of the Azeri language did not interfere with their being moved by the artists. ${ }^{55}$

Toward a Common Culture. This assurance that artistic communication could overcome any and all potential barriers to mutual comprehension, and thus harmony, among the brotherhood of man resolves into another feature of dekada commentary: the declaration that the festivals had made the culture of one ethnic group into a common Soviet cultural asset. During Georgia's dekada in January 1937, an article in Pravda explained that Moscow adopts the best products of the cultures of brother republics, while Kerzhentsev opined in the press about Georgian operas that should be part of the standard repertory. ${ }^{56}$ Nearly a year earlier, after Ukraine held its dekada

in Moscow (See I. Kaplan, The Art of Nation-building, chapter 4), which was followed by the Dekada of Armenian Literature in 1941. After the war, dekady of national art began to encompass all branches of creative production (literature, music, dance, theater, film, visual and plastic arts, etc.) and were officially referred to as dekady of national art and literature.

51 Such translation activities were taken up in connection with the Pushkin Centennial in 1937 and thereafter by national republics in connection with their national poet jubilees.

52 Pravda, March 23, 1936, 4; She went on to credit the present flourishing of Ukrainian art to Soviet rule and the nationalities policy of Lenin and Stalin.

53 P. Kerzhentsev, "Kazakhskoe iskusstvo," Pravda, May 24, 1936, 4; The operas were KyzZhybek and Zhalbyr.

54 V. Gorodinskii, “Zakliuchitel'nyi kontsert,” Pravda, October 30, 1939.

55 “Hər sahədə qələbə uorunda mübarizəjə!" Qommunist, April 14, 1938.

56 Pravda, January 7, 1937; Pravda, January 15, 1937; A similar piece ran in Literaturnaia gazeta on the same date. 
in Moscow, a Komsomolskaia Pravda article announced, "Ukrainian art is becoming the property of all the peoples of the country... All the best created by peoples in the past... flows into the mainstream of socialist culture." ${ }^{57}$ In his appraisal of the Dekada of Kazakh Art in 1936, Kerzhentsev commented that "a number of Kazakh motifs will enter our common musical frame of reference," adding that several arias from Kazakh operas set to be published in Russian translation would "doubtless prove popular," a signal that knowledge of high Kazakh art had become a requisite part of Soviet cultural literacy for the kul 'turnyi person. ${ }^{58}$ Thanks to the festival, wrote first secretary of Kazakhstan's Communist Party Levon Mirzoian, "Kazakh legends, songs, and folklore have become known to the entire country." ${ }^{59}$ Similarly, a 1940 article praising the institution of the dekada mentions that "after each dekada, the best works of national art appear in the repertoire of Moscow, Leningrad, and other theaters." ${ }^{60}$ Georgian composer Zakharii Paliashvili's opera Abesalom and Eteri entered the repertoire of the Bolshoi Theater, and plans were made for the Azerbaijani opera Koroğlu to do the same. ${ }^{61}$

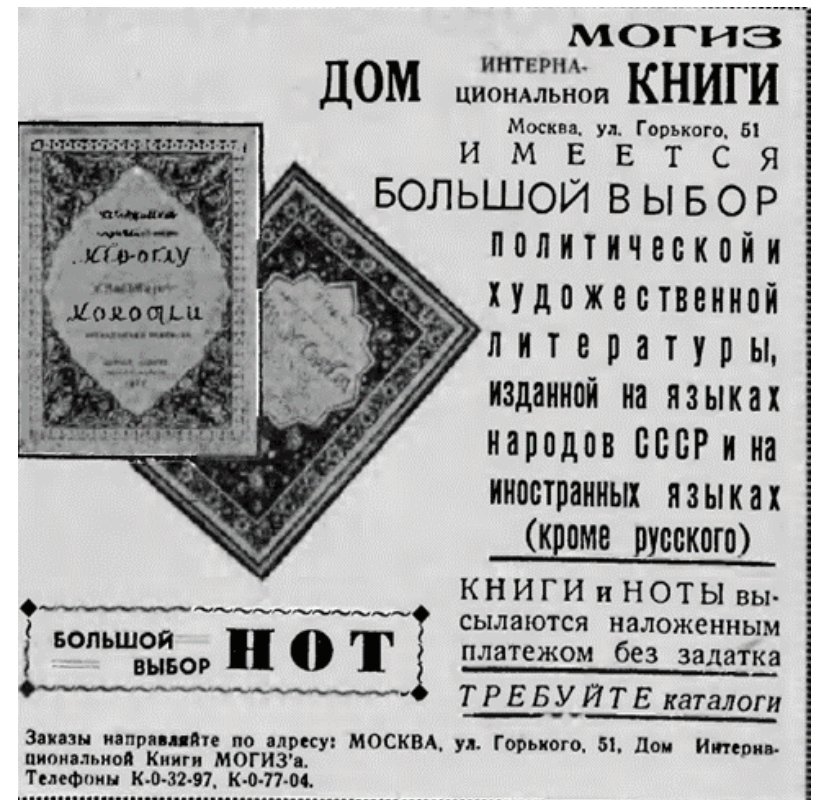

Figure 1. Moscow bookstore advertisement featuring the score of a new Azerbaijani opera Koroğlu

Notes: The opera Koroğlu had its Moscow premiere during the Dekada of Azerbaijani Art in April 1938. In May, Moscow's Bolshoi Theater added the opera to its repertoire.

Source: Literaturnaia gazeta, May 10, 1938, 6.

57 “Torzhestvo sovetskoi kul’tury,” Komsomolskaia Pravda, March 24, 1936; Bold in original.

58 Pravda, May 24, 1936, 4.

59 "Kazakhstan-soiuznaia respublika," Bol'shevik, no. 4, 1937, 25; Quoted in Martin, The Affirmative Action Empire, 445; Mirzoian had been sent to Kazakhstan in 1935 after being removed from his post in Azerbaijan.

60 Pravda, October 5, 1940, 1.

${ }_{61}$ Abesalom and Eteri was removed from the Bolshoi's repertoire after two seasons, however, and the Bolshoi production of Koroğlu was canceled during rehearsals. See Kaplan, The Art of Nation-building, Chapter 3. 
During the dekada planning process in Azerbaijan, which had experienced difficulty getting central publishing houses to publish its cultural products, the chair of the republic's Sovnarkom said, "If we present things right, we won't have to raise the question. They'll come to us themselves." ${ }^{2}$ Sure enough, following Azerbaijan's festival of national art in 1938, the score of Koroğlu, a new Azerbaijani opera that had made its Moscow premiere during the dekada, went on sale in the capital (see Figure 1).

Letters from amateur clubs and professional theaters all over Russia and the Soviet Union to Azerbaijan's Directorate of Artistic Affairs requesting to purchase sheet music of works presented in the Azerbaijani dekada indicate that organizations throughout the USSR were picking up on the center's signal to engage with the touchstone artistic products of the various cultures of the brother republics. ${ }^{63}$

\section{Conclusion}

While the dekady of national art in Moscow are, on one hand, another iteration of highly choreographed Soviet propaganda epitomizing well-known strands of Stalin-era culture, they also stand out as a Soviet multiethnic initiative that yielded some notable results. As the festivals provided the framework within which national art was produced, presented, and disseminated, they were a significant event in the lives of Soviet nations and in the life of Soviet nation-building. At the same time, they furnished cross-cultural exposure that broadened the horizons of many. Certainly, there were those on the periphery who resented Moscow's diktats and critiques, viewing any efforts to "modernize" national art or make it accessible to those beyond the nation as distorting exercises. Likewise, there were those in the center who did not welcome non-Russians to the Bolshoi stage and resented the investment of resources in the cultures of the periphery.

Still, the unique dekada format of highlighting one republic at a time paid reassuring homage to the separateness of each Soviet national group, even as Russian Moscow asserted itself as culturally dominant. ${ }^{64}$ Taking a cue from the production-consumption nexus at the core of Stakhanovism, the dekady equated the popularization of national cultures with acknowledgment of nationhood, as if the litmus test for nationhood were not merely the production of a national culture but its presentation to and consumption by those outside the nation. This Soviet understanding of national development posited an interdependence between art and nation, between production and consumption, and between national and international, in which the elements of each pair were mutually defining and mutually reinforcing. These relationships were enshrined in Friendship of Peoples imperatives, which institutions such as the dekada of national art were devised

62 ARDA, f. 411, siy. 19, iş 201, səh. 12.

63 ARDӘİA, f. 345, siy. 1, iș 77, səh. 14; f. 254, siy.1, iș 82, səh. 31; f. 254, siy. 1, iș 17, səh. 17. There had been similar developments after other dekady. The Rostov oblast' symphony orchestra included Gul'sara, a work presented during Uzbekistan's 1937 dekada, in its repertoire for the 1938-39 season, and in fall 1939 it presented the Georgian opera Keto and Kote (ARDӘİA, f. 345, siy. 1, iş 77, səh. 237-237 tərs tərəf.; Sovetskoe iskusstvo, October 24, 1939).

64 I am drawing here on Yuri Slezkine's comment that in the metaphorical Soviet "communal apartment" of the 1930s, even as the "Russians began to bully their neighbors" and the "tenants were increasingly unequal," they remained "reassuringly separate," with each entitled to their own room. Slezkine, "The USSR as a Communal Apartment," 443-4. 
to satisfy by systematizing the cross-cultural interaction necessary to forge a unified Soviet identity. The Friendship of Peoples provided the multicultural audience needed to make national art universal. In this way, it was transformational.

While the ritual consumption of the arts dekady certainly did not collapse hierarchies, it did succeed in pointing up the possibility of constructing an all-Union, multiethnic artistic canon, and, arguably prefiguring debates about multiculturalism that were taken up elsewhere only decades later. Finally, at an arts dekada, each nation's presentation of its artistic output for consumption by the all-Union audience was a cultural transaction through which the individual nation contributed to building a common Soviet culture. In exchange, the individual "producer" nation was validated. Perhaps this transactional dynamism made the dekada of national art a more interesting and satisfying exercise than other sorts of all-Union projects, such as Red Square parades or the "Istoriia narodov SSSR" in which each nation's self-contained contribution, whether youth marching in formation or historical narrative, simply took its place in line.

Рукопись поступила: 1 ноября 2019 г.

Submitted: 1 November 2019

\section{References}

Brooks, Jeffrey. Thank You, Comrade Stalin! Soviet Public Culture from Revolution to Cold War. Princeton, NJ: Princeton University Press, 2000.

Dobrenko, Evgenii. "Naideno v perevode: rozhdenie sovetskoi mnogonatsional'noi literatury iz smerti avtora." Neprikosnovennyi zapas, no. 4 (July - August 2011): 236-262 (in Russian).

Dumitru, Diana, and Johnson, Carter. "Constructing Interethnic Conflict and Cooperation: Why Some People Harmed Jews and Others Helped Them during the Holocaust," World Politics 61, no. 1 (January 2011): 1-42.

Dzhanaliev, K. Iskusstvo Sovetskoi Kirgizii. Moscow: Iskusstvo, 1939 (in Russian).

Fowler, Mayhill C. Beau Monde on Empire's Edge: State and Stage in Soviet Ukraine. Toronto: University of Toronto Press, 2017.

Frolova-Walker, Marina. " 'National in Form, Socialist in Content': Musical Nation-Building in the Soviet Republics." Journal of the American Musicological Society 51, no. 2 (Summer 1998): 331-371.

Frolova-Walker, Marina. "The Soviet Opera Project: Ivan Dzerzhinsky vs. Ivan Susanin.” Cambridge Opera Journal 18, no. 2 (July 2006): 181-216.

Kaplan, Isabelle R. The Art of Nation-building: National Culture and Soviet Politics in Azerbaijan and Other Minority Republics. PhD diss., Georgetown University, 2017.

Kotkin, Stephen. Magnetic Mountain: Stalinism as Civilization. Berkeley, CA: University of California Press, 1995.

Martin, Terry. The Affirmative Action Empire: Nations and Nationalism in the Soviet Union, 1923-1939. Ithaca, NY: Cornell University Press, 2001.

Moisenko, Rena. Realist Music: 25 Soviet Composers. London: Meridian Books, 1949.

Petrone, Karen. Life Has Become More Joyous, Comrades: Celebrations in the Time of Stalin. Bloomington, IN: Indiana University Press, 2000.

Shaw, Matthew. Time and the French Revolution: A History of the French Republican Calendar, 1789-Year XIV. Woodbridge, UK: The Boydell Press, 2011. 
Siegelbaum, Lewis H. Stakhanovism and the Politics of Productivity in the USSR, 1935-1941. New York: Cambridge University Press, 1988.

Slezkine, Yuri. "The USSR as a Communal Apartment, or How a Socialist State Promoted Ethnic Particularism." Slavic Review 53, no. 2 (Summer 1994): 414-52.

Yekelchyk, Serhy. "Diktat and Dialogue in Stalinist Culture: Staging Patriotic Historical Opera in Soviet Ukraine, 1936-1954.” Slavic Review, No. 59/3 (Autumn 2000): 597-624.

\section{Информация об авторе / Information about the author}

Каплан Изабель Рут, доктор исторических наук (PhD in History), научный сотрудник Международного центра истории и социологии Второй мировой войны и ее последствий Национального исследовательского университета «Высшая школа экономики» (Москва, Россия); приглашенный доцент Института европейских, российских и евразийских исследований, Школа международных отношений имени Эллиотта, Университет Джорджа Вашингтона (США).
Isabelle R. Kaplan, $\mathrm{PhD}$ in History, Post-Doctoral Fellow, International Centre for the History and Sociology of World War II and Its Consequences, National Research University Higher School of Economics (Moscow, Russia); Visiting Assistant Professor, Institute for European, Russian, and Eurasian Studies, Elliott School of International Affairs, George Washington University (USA). 